\title{
Analisis Penggunaan Teknologi Informasi Dalam Penyusunan Laporan Keuangan Pada UMKM di Kota Pekanbaru
}

\author{
SATRIA TRI NANDA ${ }^{1}$; NENENG SALMIAH ${ }^{2}$ \\ 1,2 Universitas Lancang Kuning, \\ Jl. Yos Sudarso KM 08 Rumbai-Pekanbaru, Indonesia, 28265 \\ E-mail: satriatrinanda@unilak.ac.id
}

\begin{abstract}
This study aims to analyze the use of information technology in the process of financial reporting on SMEs in Pekanbaru City. To analyze the use of information technology at SMEs Pekanbaru City by asking a questionnaire to UMKM entrepreneurs so that obtained an explanation of the use of information tekology that has been used. Measurement of the use of information technology consisting of: Duration of Computer Use, Frequency of Computer Usage, Application Diversity Used, and Types of Financial Statements. Data processing is done by descriptive analysis method using SPSS version 20 application through frequency distribution, graph, and analysis mode. From the results of research found that SMEs in Pekanbaru City has not been maximized in the use of information technology.
\end{abstract}

Keywords: Use of Information Technology, Financial Statements

Masalah umum yang dihadapi oleh pengusaha UMKM seperti keterbatasan modal kerja, kesulitan bahan baku, keterbatasan teknologi, sumber daya manusia dengan kualitas yang baik, informasi dan pemasaran (Astuti dan Widianti, 2003). lemahnya usaha kecil di Indonesia disebabkan oleh kombinasi oleh berbagai faktor, antara lain keterbatasan sumber daya manusia, teknologi, modal, dan informasi tetapi juga karena kurangnya dukungan dari pemerintah dan kemauan pengusaha-pengusaha UMKM untuk berorientasi global.

Akan tetapi, dari berbagai permasalahan UMKM, permasalahan yang paling sering dieluhkan oleh UMKM adalah masalah permodalan. Untuk memperoleh permodalan yang memadai bagi perkembangan usaha UMKM, pemeritah dan pihak perbankan yang ada di Indonesia telah banyak melakukan program pembiayaan bagi UMKM. Salah satu program pemerintah terkait pembiayaan UMKM adalah Kredit Usaha Rakyat (KUR). Sejumlah kalangan menilai penyaluran KUR bisa menjadi perangsang bagi pertumbuhan kredit mikro, kecil, dan menengah (UMKM) yang hingga Mei 2015 mengalami tren perlambatan.

Berdasarkan data Departemen Statistik Moneter \& Fiskal Bank Indonesia, hingga Mei 2015 penyaluran kredit UMKM terus melambat. Pertumbuhan kredit di segmen ini tercatat 9,3\% menjadi Rp694,7 triliun. Pertumbuhan ini lebih rendah dibandingkan dengan pertumbuhan total kredit yang mencapai $10,3 \%$. Majalah bisnis mencatat, dalam empat tahun terakhir pertumbuhan kredit UMKM selalu lebih rendah dibandingkan dengna pertumbuhan total kredit. Rata-rata pertumbuhan kredit UMKM dalam empat tahun terakhir mencapai 12,54\% sedangkan rata-rata pertumbuhan total kredit mencapai 16,63\%. (Bisnis.Tempo.Co : 2015).

Penyebab rendahnya penyaluran KUR tersebut karena bank yang ditunjuk sebagai penyalur KUR masih terlalu berhati-hati dalam penyaluran kredit, karena tidak memiliki akses informasi yang memadai terkait kondisi UMKM (kementerian Kopreasi dan UMKM, 2013). Oleh karena itu yang menjadi salah satu persyaratan pemberian kredit atau 
pembiayaan oleh bank umum dalam rangka pengembangan UMKM adalah informasi akuntansi berupa laporan keuangan yang harus disediakan oleh UMKM.

Ketidakmampuan menyediakan dan menggunakan informasi akuntansi merupakan faktor utama yang menimbulkan permasalahan dan mengakibatkan kegagalan usaha kecil dan menengah dalam pengembangan usaha (Astuti dan Widianti, 2003). Ketidakmampuan menyediakan dan menggunakan informasi akuntansi merupakan salah satu kelemahan dari sisi manajemen. Kelemahan ini merupakan faktor utama yang mengakibatkan kegagalan UMKM dalam mengembangkan usaha. Kemampuan untuk menyediakan dan menggunakan informasi akuntansi sangat tergantung kepada kemampuan pemilik untuk menjalankan teknis akuntansi (Theng dan Jasmine, 1996).

Proses penyusunan laporan keuangan pada era teknologi informasi dapat mempermudah penyusunan laporan keuangan. Beberapa penelitian terdahulu telah dilakukan untuk mengetahui peran teknologi informasi terhadap penyusunanan lpaoran keuangan. Xiao et al (1996) menemukan bahwa teknologi informasi berperan besar dalam berbagai aspek seperti efesiensi, dan efektifitas sistem yang bersifat prosedural pelaporan internal dan eksternal. Hamilton dan Asundi (2008) menemukan teknologi informasi berdampak pada produktifitas dan pertumbuhan profitabilitas UMKM di Puerto Rico. Sutton (2000) mengemukaan pentingnya teknologi informasi terhadap penyediaan laporan keuagan secara tepat waktu. Penelitian tentang penggunaan teknologi informasi juga di lakukan oleh Sabihaini (2006), yang menemukan bahwa faktor yang mempengaruhi penggunaan teknologi informasi antara lain faktor sosial, kompleksitas, job-fit, konsekuensi jangka panjang, kondisi yang memfasilitasi, dan kinerja individu.

Berdasarkan hasil penelitian terdahulu, penelitian ini mencoba untuk Jurnal Daya Saing menganalisis dan mengetahui bagaimana penggunaan teknologi informasi yang digunakan oleh UMKM dalam proses bisnis yang mereka jalani. Penelitian ini akan melihat dari 4 aspek yaitu : durasi penggunaan komputer, frekuensi penggunaan komputer, jenis aplikasi yang digunakan, dan jenis laporan keuangan yang dihasilkan.

Laporan keuangan adalah bagian dari proses pelaporan keuangan. Keadaan Sebuah perusahaan akan tergambar dalam laporan yang disajikan oleh bagian akuntansi sebuah perusahaan atau badan usaha. Laporan keuangan terdari dari beberapa komponen antara lain neraca, laporan laba rugi serta laporan keuangan lainnya. Riswan dan Kesuma (2014) menjelaskan laporan keuangan adalah catatan informasi keuangan suatu perusahaan pada suatu periode akuntansi yang dapat digunakan untuk menggambarkan kinerja perusahaan. Sedangkan Baridwan (2004) mendefinisikan laporan keuangan merupakan ringkasan dari suatu proses pencatatan, merupakan suatu ringkasan dari taransaksi-transaksi keuangan yang terjadi selama tahun buku yang bersangkutan.

Jika dilihat dari pihak yang berkepentingan, ada tiga jenis laporan keuangan yang akan disajikan oleh divisi akuntansi perusahaan. antara lain laporan keuangan untuk manajmen, laporan keuangan untuk pihak eksternal perusahaan, dan laporan keuangan untuk pihak-pihak khusus. Laporan keuangan untuk ketiga pihak tersebut disusun dan disajikan dari suatu proses akuntansi yang sama, yaitu merupakan produk dari sebuah system informasi akuntansi.

Riswan dan Kesuma (2014) menjelaskan para pemakai laporan akan menggunakan untuk meramalkan, membandingkan, dan menilai dampak keuangan yang timbul dari keputusan ekonomis yang diambil. Informasi mengenai dampak keuangan yang timbul tadi sangat berguna bagi pemakai untuk

$$
\text { p.ISSN: 2407-800X e.ISSN: 2541-4356 }
$$


meramalkan, membandingkan dan menilai keuangan. Seandainya nilai uang tidak stabil, maka hal ini akan dijelaskan dalam laporan keuangan. Laporan keuangan akan lebih bermanfaat apabila dilaporkan tidak saja aspek-aspek kuantitatif, tetapi mencakup penjelasanpenjelasan lainnya yang dirasakan perlu. Dan informasi ini harus faktual dan dapat diukur secara objektif.

Perkembangan teknologi informasi (TI) yang pesat sangat berdapak pada perkembangan dunia akuntansi dan auditing. Kemajuan TI mempengaruhi perkembangan sistem informasi akuntansi (SIA) dalam hal pemrosesan data, pengendalian intern, dan peningkatan jumlah dan kualitas informasi dalam pelaporan keuangan. Darwanis dan Mahyani (2009) menungkapkan TI merupakan teknologi yang mempunyai kemampuan yang sedemikian rupa untuk menangkap, menyimpan, mengolah, mengambil kembali, menampilkan, dan memberdayakan informasi. Perkembangan teknologi merupakan kombinasi antara kemajuan pesat bidang ilmu komputer dan komunikasi. (Thomson et.all , 1991) mengungkapkan penggunaan teknologi informasi didefinisikan sebagai perilaku individu dalam menggunakan teknologi informasi seperti komputer dalam kegiatan operasional perusahaan.

Pemanfaatan teknologi behubungan dengan perilaku menggunakan teknologi tersebut untuk menyelesaikan tugas. Teori sikap dan perilaku dari Triandis (1980) dalam Jurnali (2001) menyatakan bahwa pemanfaatan computer personal oleh pekerja yang memiliki pengetahuan di lingkungan yang dapat memilih, akan dipengaruhi oleh perasaan individual terhadap penggunaan computer personal, norma sosial dalam tempat kerja yang memperhatikan penggunaan computer personal, kebiasaan sehubungan dengan penggunaan computer, konsekuensi individual yang diharapkan dari penggunaan computer personal dan kondisi yang memfasilitasi dalam lingkungan yang Jurnal Daya Saing kondusif dalam penggunaan computer personal.

Pengukuran variabel penggunaan teknologi informasi dilakukan dengan menggunakan kuesioner yang diadopsi dari Thomson et.all, (1991). Kuesioner terdiri atas 4 pertanyaan yang berisi empat indikator yaitu intensitas penggunaan, frekuensi penggunaan, keragaman jenis software yang digunakan, dan jumlah laporan atau output yang dihasilkan. Intensitas penggunaan diukur dengan menggunakan 5 kategori waktu mulai dari kurang dari 15 menit (kategori 1) sampai lebih dari 120 menit (kategori 5). Frekuensi penggunaan diukur dengan empat kategori mulai dari kurang dari satu minggu sampai beberapa kali dalam sehari. Keragaman software yang digunakan diukur dengan menghitung berapa jumlah software yang digunakan dalam kegiatan operasional.

\section{METODE}

Objek penelitian ini merupakan penggunaan teknologi informasi pada UMKM yang ada di Pekanbaru. UMKM di Pekanbaru dijadikan objek penelitian karena dapat mewakili latarbelakang penelitian ini dilakukan. Sampel dalam penelitian ini adalah UMKM yang tergabung dalam RUN. Dari hasil wawancara dengan Ketua RUN Kota Pekanabaru diketahui jumlah UMKM yang tersebar di seluruh Kota Pekanbaru berjumlah lebih dari 200. Sampel pada penelitian ini adalah anggota koperasi yang memiliki usaha yang di ketahui pada saat pengisian kolom deskripsi responden yang terdapat pada kuesioner.

Adapun jenis penelitian ini adalah penelitian survai (survey research) yang berupa penelitian explanatory. Teknik pengambilan sampel pada penelitian ini di dasarkan kepada pendapat Gay dalam Umar (2009) yang menyatakan bahwa jumlam minimal sampel adalah $10 \%$ dari populasi. Oleh karena itu maka penelitian ini menetapka jumlah sampel sebesar : $20 \% \mathrm{x}$ $200=40$ pelaku UMKM yang tergabung di

p.ISSN: $2407-800 X \quad$ e.ISSN: 2541-4356 
dalam RUN. Adapun kriteria dalam pengambilan sampel ini sebagai berikut. Anggota RUN yang memiliki usaha mikro, kecil, dan menengah (UMKM) dan Umur usaha lebih dari satu tahun. Penelitian ini mencoba untuk menganalisis penggunaan teknologi informasi yang menjadi objek penelitian. Data yang digunakan dalam penelitian ini adalah data primer. Data primer diperoleh dengan menggunakan daftar pertanyaan yang tergabung dalam sebuah kuesioner yang telah terstruktur dengan tujuan untuk mengumpulkan informasi dari objek penelitian.

Dalam penelitian ini penulis melakukan analisis deskriptif dengan membuat analisis distribusi frekuensi, grafik, dan analisa modus untuk memberikan gambaran mengenai kecenderungan tanggapan responden terhadap variabel penelitian. Pengujian data penelitian menggunakan aplikasi SPSS versi 20.

\section{HASIL}

Penelitian ini menggunakan penyebaran kuesioner secara langsung kepada pemilik UMKM yang tergabung dalam RUN di Kota Pekanbaru dengan total kuisioner sebanyak 45 responden. Tabel berikut ini menunjukkan sampel dan tingkat pengembalian kuesioner.

Tabel 1: Sampel dan Tingkat Pengembalian Kuesioner

\begin{tabular}{|l|l|l|}
\hline Keterangan & Jumlah & Persentase \\
\hline $\begin{array}{l}\text { Total kuesioner yang } \\
\text { dibagikan }\end{array}$ & 45 & $91,2 \%$ \\
\hline $\begin{array}{l}\text { Total kuesioner yang } \\
\text { tidak lengkap }\end{array}$ & 4 & $8,8 \%$ \\
\hline $\begin{array}{l}\text { Total kuesioner yang } \\
\text { lengkap dan dapat } \\
\text { diolah }\end{array}$ & 90 & $91,2 \%$ \\
\hline
\end{tabular}

Sumber: Data primer yang diolah tahun 2017

Tabel 1 memberikan gambaran mengenai tingkat pengembalian kuesioner. Kuesioner disebarkan kepada pemilik UMKM yang tergabung dalam RUN di Kota Pekanbaru. Keseluruhan kuesioner yang dibagikan yaitu 45 kuesioner $(91,2 \%)$. Semua kuesioner yang dibagikan dikembalikan, akan tetapi terdapat beberapa kuisioner yang tidak dapat digunakakn karna tidak diisi secara lengkap. Maka total kuisioner yang dapat diolah adalah sebanyak 91,2 persen atau 41 kuisioner. Hasil pengujian data secara deskriptif menggunakan pengujian modus didapat hasil sebagaimana ditunjukkan dalam tabel 2 dibawah ini :

Tabel 2. Tabel Perhitungan Modus

\begin{tabular}{|c|c|c|c|c|}
\hline \multicolumn{5}{|c|}{ Statistics } \\
\hline & $\begin{array}{l}\text { Durasi } \\
\text { penggunaan } \\
\text { komputer }\end{array}$ & $\begin{array}{l}\text { Frekuensi } \\
\text { menggunakan } \\
\text { komputer }\end{array}$ & $\begin{array}{l}\text { Keragaman } \\
\text { aplikasi yang } \\
\text { digunakan }\end{array}$ & $\begin{array}{l}\text { Jenis } \\
\text { laporan } \\
\text { keuangan }\end{array}$ \\
\hline Valid & 41 & 41 & 41 & 41 \\
\hline${ }^{N}$ Missing & 0 & 0 & 0 & 0 \\
\hline Mode & 4,00 & 4,00 & 2,00 & 2,00 \\
\hline \begin{tabular}{|l} 
Std. \\
Deviation
\end{tabular} & 1,21223 & 1,24450 &, 70365 & 1,21324 \\
\hline Minimum & 1,00 & 1,00 & 1,00 & 1,00 \\
\hline Maximum & 5,00 & 5,00 & 4,00 & 5,00 \\
\hline
\end{tabular}

Durasi Penggunaan Komputer.

Hasil pengujian yang dilakukan pada variabel durasi penggunaan komputer memperoleh nilai modos sebesar 4,00 dengan total frequency 14 . Hal ini berarti bahwa dari UMKM yang tergabung dalam RUN paing sering menggunakan komputer pada rentang waktu 60-90 menit. Adapun banyaknya UMKM yang menggunakan komputer selama 60-90 menit adalah 14 UMKM.

Tabel. 3 Durasi penggunaan komputer

\begin{tabular}{|c|c|c|c|c|c|}
\hline & & Frequency & Percen & $\begin{array}{l}\text { Valid } \\
\text { Percent }\end{array}$ & $\begin{array}{l}\text { Cumulative } \\
\text { Percent }\end{array}$ \\
\hline \multirow{6}{*}{ Valid } & tidak pernah & 5 & 12,2 & 12,2 & 12,2 \\
\hline & \begin{tabular}{|l|} 
kurang dari \\
15 menit
\end{tabular} & 9 & 22,0 & 22,0 & 34,1 \\
\hline & 30 - 45 menit & 9 & 22,0 & 22,0 & 56,1 \\
\hline & $60-90$ menit & 14 & 34,1 & 34,1 & 90,2 \\
\hline & $\begin{array}{l}\text { lebih dari } 120 \\
\text { menit }\end{array}$ & 4 & 9,8 & 9,8 & 100,0 \\
\hline & Total & 41 & 100,0 & 100,0 & \\
\hline
\end{tabular}

Sumber: Data primer yang diolah tahun 2017

Frekuensi Menggunakan Komputer.

Hasil pengujian yang dilakukan pada variabel Frekuensi Menggunaan komputer memperoleh nilai modos sebesar 4,00 dengan total frequency 20. Hal ini berarti bahwa dari UMKM yang tergabung dalam RUN paing sering menggunakan 
komputer paling sedekit 1 hari sekali, atau dalam arti setiap hari UMKM telah menggunakan komputer dalam proses pembuatan laporan keuangan. Adapun banyaknya UMKM yang menggunakan komputer 1 hari sekali adalah 20 UMKM.

Tabel 4: Frekuensi menggunakan komputer

\begin{tabular}{|c|c|c|c|c|}
\hline & Frequency & Percen & Valid & Cumulative \\
\hline tidak pernah & 5 & 12,2 & 12,2 & 12,2 \\
\hline 1 - 2 kali sebulan & 5 & 12,2 & 12,2 & 24,4 \\
\hline 1 - 2 kali seminggu & 5 & 12,2 & 12,2 & 36,6 \\
\hline Valid 1 kali perhari & 20 & 48,8 & 48,8 & 85,4 \\
\hline 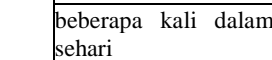 & 6 & 14,6 & 14,6 & 100,0 \\
\hline Total & 41 & 100,0 & 100,0 & \\
\hline
\end{tabular}

Sumber : Data primer yang diolah tahun 2017

Hasil pengujian yang dilakukan pada variabel keragaman aplikasi yag digunakan memperoleh nilai modos sebesar 2,00 dengan total frequency 23 . Hal ini berarti bahwa dari UMKM yang tergabung dalam RUN paling sering haya menggunakan 1 aplikasi penyusunan laporan keuangan saja. Adapun banyaknya UMKM yang menggunakan 1 software akuntansi dala penyusunan laporan keuangan adalah sebanyak 23 UMKM..

Tabel 5: Keragaman aplikasi yang digunakan

\begin{tabular}{|c|c|c|c|c|}
\hline & \multirow{2}{*}{ Frequenc } & \multicolumn{2}{|c|}{ yPercentValid } & \multirow{2}{*}{$\begin{array}{l}\text { Cumulative } \\
\text { Percent }\end{array}$} \\
\hline & & & Percent & \\
\hline tidak ada & 6 & 14,6 & 14,6 & 14,6 \\
\hline $\begin{array}{lll}\text { hanya } & 1 & \text { jenis } \\
\text { software } & \end{array}$ & 23 & 56,1 & 56,1 & 70,7 \\
\hline Valid 2 jenis software & 11 & 26,8 & 26,8 & 97,6 \\
\hline 3 jenis software & 1 & 2,4 & 2,4 & 100,0 \\
\hline Total & 41 & 100,0 & 100,0 & \\
\hline
\end{tabular}

Sumber : Data primer yang diolah tahun 2017

Jenis Laporan Keuangan.

Hasil pengujian yang dilakukan pada variabel keragaman aplikasi yag digunakan memperoleh nilai modos sebesar 2,00 dengan total frequency 15 . Hal ini berarti bahwa dari UMKM yang tergabung dalam RUN hanya menggunakan 1 jenis laporan keuangan saja. Adapun banyaknya UMKM yang menghasilkan 1 jenis laporan keuangan saja adalah sebanyak 15 UMKM.
Tabel 6. Jenis laporan keuangan

\begin{tabular}{|c|c|c|c|c|}
\hline & & \multicolumn{2}{|c|}{ Percent Valid } & \multirow{2}{*}{$\begin{array}{l}\text { Cumulative } \\
\text { Percent }\end{array}$} \\
\hline & & & Percent & \\
\hline tidak ada & 6 & 14,6 & 14,6 & 14,6 \\
\hline $\begin{array}{ll}1 & \text { jenis } \\
\text { laporan }\end{array}$ & 15 & 36,6 & 36,6 & 51,2 \\
\hline $\begin{array}{l}1-3 \text { jenis } \\
\text { laporan }\end{array}$ & 11 & 26,8 & 26,8 & 78,0 \\
\hline 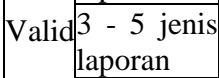 & 4 & 9,8 & 9,8 & 87,8 \\
\hline $\begin{array}{ll}\text { lebih } & \text { dari } \\
5 & \text { jenis } \\
\text { laporan }\end{array}$ & & 12,2 & 12,2 & 100,0 \\
\hline Total & 41 & 100,0 & 100,0 & \\
\hline
\end{tabular}

Sumber: Data primer yang diolah tahun 2017

\section{PEMBAHASAN}

Durasi penggunaan komputer pada UMKM yang tergabung dalam RUN paling banyak dilakukan hanya dalam durasi 60-90 menit sehari. Durasi ini dilakukan oleh 14 UMKM atau $34,15 \%$ dari total UMKM yang menjadi sampel penelitian. UMKM yang telah menggunakan komputer lebih dari 120 menit hanya berjumlah 4 UMKM atau $9,67 \%$. UMKM yang menggunakan komputer dalam durasi 30-45 menit adalah sebanyak 9 UMKM atau 21,95\%. UMKM yang menggunakan komputer kurang dari 15 menit sebanyak 9 UMKM atau 21,95\%. UMKM yang tidak pernanh menggunakan komputer sebanyak 5 atau $12,20 \%$.

Dilihat dari hasil diatas durasi penggunaan komputer oleh pelaku UMKM yang tergabung didalam RUN terlihat sangat rendah, hal ini dikarenakan UMKM yang menggunakan komputer lebih dari 120 menit hanya 4 UMKM. Dapat diprediksi rendahnya penyaluran KUR dan tidak berkembanganya UMKM di Indonesia terkhusus Pekanbaru dikarenakan tidak maksimalnya durasi penggunaan komputer atau teknologi dalam menyajikan laporan keuangan, sedangkan dalam tuntutan dunia usaha saat ini diperlukan laporan keuangan yang dapat dipercaya dan diperoleh tepat waktu.

Jika dilihat dari hasil penelitian terdahulu, wajar saja jika penyaluran KUR pada UMKM di Pekanbaru masih rendah dan UMKM tersa sulit untuk berkembang. 
Hamilton dan Asundi (2008) menyatakan bahwa teknologi informasi berdampak pada produktifitas dan pertumbuhan profitabilitas UMKM di Puerto Rico. Selain Sutton (2000) mengemukaan pentingnya teknologi informasi terhadap penyediaan laporan keuagan secara tepat waktu. Jika dilihat dari temuan penelitian terdahulu dapat disimpukan UMKM harus lebih maksimal dalam durasi penggunaan komputer agar dapat memperoleh pembiayaan dan dapat menyajikan laporan keuangan yang akuntabel.

Tidak jauh berbeda dari hasil durasi penggunaan komputer, frekuensi penggunaan komputer pada UMKM yang tergabung dalam RUN juga terhitung dinilai masih rendah. UMKM paling banyak menggunakan komputer 1 kali 1 hari. Durasi ini dilakukan oleh 20 UMKM atau 48,78\% dari total UMKM yang menjadi sampel penelitian. UMKM dengan frekuensi beberapa kali satu hari hanya berjumlah 6 UMKM atau 14,63\%. UMKM dengan frekuensi 1-2 kali seminggu sebanyak 5 UMKM atau 12,20\%. UMKM dengan frekuensi 1-2 kali dalam sebulan sebanyak 5 UMKM atau 12,20\%. UMKM yang tidak pernah menggunakan komputer sebanyak 5 atau $12,20 \%$.

Dilihat dari hasil diatas frekuensi penggunaan komputer oleh pelaku UMKM yang tergabung didalam RUN terlihat sangat rendah, karena hanya 6 UMKM yang mengunakan komputer dalam frekuensi beberapakali atau selalu digunakan dalam sehari. Hal ini juga dapat memprediksi rendahnya penyaluran KUR dan tidak berkembanganya UMKM di Indonesia terkhusus Pekanbaru dikarenakan tidak maksimalnya frekuensi penggunaan komputer atau teknologi dalam menyajikan laporan keuangan, sedangkan dalam tuntutan dunia usaha saat ini diperlukan laporan keuangan yang dapat dipercaya dan diperoleh tepat waktu.

Sama halnya dengan durasi penggunaan komputer, frekuensi penggunaan komputer juga menjadi salah satu penghambat KUR dapat disalurkan dengan baik dan berkembanganya UMKM. Mengacu kepada beberapa penelitian terdahulu Hamilton dan Asundi (2008) menyatakan bahwa teknologi informasi berdampak pada produktifitas dan pertumbuhan profitabilitas UMKM di Puerto Rico. Selain Sutton (2000) mengemukaan pentingnya teknologi informasi terhadap penyediaan laporan keuagan secara tepat waktu. Jika dilihat dari temuan penelitian terdahulu dapat disimpukan UMKM harus lebih maksimal dalam frekuensi penggunaan komputer agar dapat memperoleh pembiayaan dan dapat menyajikan laporan keuangan yang akuntabel.

Keragaman Aplikasi Yang Digunakan.

Pengujian Keragaman aplikasi yang digunakan oleh UMKM paling banyak menggunakan komputer 1 jenis aplikasi dalam kegiatan usaha mereka. Penggunaan 1 jenis aplikasi ini dilakukan oleh 23 UMKM atau $56,10 \%$ dari total UMKM yang menjadi sampel penelitian. UMKM yang menggunakan 3 jenis soft ware berjumlah 1 UMKM atau $2,44 \%$. UMKM dengan 2 jenis soft ware sebanyak 11 UMKM atau $26,83 \%$. UMKM yang tidak pernah menggunakan komputer sebanyak 6 atau $14,63 \%$.

Dilihat dari hasil diatas pelaku UMKM yang tergabung didalam RUN sebagian besar telah menggunakan 1 jenis aplikasi dalam operasional perusahaannya. Penggunaan jenis software tentu sangat bergantung kepada kebutuhan operasional UMKM itu sendiri. Jika kegiatan usaha masih tergolong kecil mungkin penggunaan 1 jenis software telah mencukupi kebutuhan UMKM. Namun apabila sudah dalam skala besar dan jenis barang yang dijual sudah banyak maka akan dibutuhkan beberapa aplikasi yang mendukung kegiatan usaha UMKM. Dari hasil penelitian dapat ditarik kesimpulan pada saat ini UMKM sudah mulai menggunakan aplikasi komputer dalam kegiatan operasionalnya. Hal ini tentu saja berdampak positif bagi perkembangan usaha dan kemudahan memperoleh pembiayaan dari lembaga keuangan. Semakin banyak aplikasi yang digunakan 
dalam proses operasional perusahaan maka akan semakin besar manfaat yang akan diterima oleh UMKM. Seperti hasil penelitian Xiao et al (1996) yang menemukan bahwa teknologi informasi berperan besar dalam berbagai aspek seperti efesiensi, dan efektifitas sistem yang bersifat prosedural pelaporan internal dan eksternal.

Jenis laporan pada UMKM yang tergabung dalam RUN juga terhitung dinilai masih rendah. UMKM paling banyak hanya menghasilkan 1 jenis laporan. 15 UMKM atau $36,59 \%$ dari total UMKM yang menjadi sampel penelitian hanya menggunakan atau menghasilkan 1 jenis laporan saja. UMKM yang menghasilakn lebih dari 5 jenis laporan sebanyak 5 UMKM atau 12,20\%. UMKM yang menghasilkan 3-5 jenis laporan sebanyak 4 UMKM atau 9,67\%. UMKM dengan 1-3 jenis laporan sebanyak 11 UMKM atau $26,83 \%$. UMKM yang tidak pernah menggunakan laporan sebanyak 6 atau $14,63 \%$.

Dilihat dari hasil diatas jumlah laporan yang dihasilkan oleh UMKM yang tergabung didalam RUN terlihat sangat rendah, karena hanya 5 UMKM yang menghasilkan lebih 5 laporan dan 4 UMKM yang menghasilkan 3-5 jenis laporan. Sedikitnya laporan keuangan yang dihasilkan oleh UMKM dapat memprediksi rendahnya penyaluran KUR dan tidak berkembanganya UMKM di Indonesia terkhusus Pekanbaru dikarenakan tidak dapat memenuhi kebutuhan persyaratan peminjaman dana pada lembaga keuangan dan sedikitnya informasi yang dapat diperoleh oleh calon investor. Sehingga lembaga keuangan dan investor menjadi ragu-ragu dalam memberikan pinjaman dan investasi pada UMKM tersebut.

Hasil penelitian ini membuktikan bahwa salah satu kendala dalam penyaluran KUR disebabkan tidak akuntabelnya laporan dari pihak UMKM, seperti halnya yang disampaikan oleh Purnomo (2004). Purnomo (2004) menjelaskan Pemerintah akan dapat melihat keberhasilan dari usaha para wirausahawan dengan melihat laporan kinerja yang tidak lain adalah laporan Jurnal Daya Saing keuangan usaha. Karena dengan laporan keuangan, pihak kreditor atau pihak lain yang ikut berperan dalam pengelolaan usaha, dapat melihat perkembangan kinerja usaha dan dapat mengestimasi kinerja usaha di masa yang akan datang. Untuk itu, para pengusaha mikro harus dibiasakan untuk menyusun dan menyajikan laporan keuangan sebagai salah satu upaya pengembangan usahanya. Kebiasaan ini perlu ditumbuhkan agar nantinya usaha kecil dan menengah mendapatkan kemudahan dalam mengajukan kredit usaha untuk kesuksesan usahanya.

\section{SIMPULAN}

Berdasarkan temuan dan pembahasan di atas dapat disimpulkan durasi penggunaan komputer pada UMKM Kota Pekanbaru masih sangat rendah. Selain durasi yang memperoleh nilai rendah, frekuensi penggunaan komputer pada UMKM Kota Pekanbaru juga masih sangat rendah. Hal lainnya yang ditemukan adalah keragaman aplikasi (software) yang digunakan oleh UMKM Kota Pekanbaru sudah menggunakan 1 aplikasi dalam pembuatan laporan. Selanjutnya jenis laporan yang dihasilkan masih sangat rendah.

\section{DAFTAR RUJUKAN}

Astuti, 2003, Pengaruh Karakteristik Internal Perusahaan terhadap Penyiapan dan Penggunaan Informasi Akuntansi Perusahaan Kecil dan Menengah di Kabupaten Kudus, Thesis dipublikasikan, UNDIP.

Baridwan, Zaki .2008. Intermediate Accounting. Edisi delapan. Cetakan kedua. BPFE-Yogyakarta.

Darwanis \& Mahyani, D.D. 2009. Pengaruh Kapasitas Sumber Daya Manusia, Pemanfaatan Tehnologi Informasi Dan Pengendalian Intern Akuntansi Terhadap Keterandalan

p.ISSN: $2407-800 X \quad$ e.ISSN: 2541-4356 
Pelaporan Keuangan Pemerintah Daerah. Jurnal telaah \& riset akuntansi. Vol. 2. No. 2 juli 2009 hal. 133-151.

Hamilton, L.C \& Asundi, R. (2008). Technology Usage And Innovation (Its Effect on the profitability of SMEs. Management Research News, Vol. 31 No. 11, 2008 pp. 830-845.

Jurnali, Teddy. 2001. Analisis Pengaruh Faktor Kesesuaian Tugas-Teknologi dan Pemanfaatan Teknologi Informasi Terhadap Kinerja Akuntan Publik. Simposium Nasional Akuntansi IV. 2001.

Riswan \& Kesuma.Y.F. 2014. Analisis Laporan Keuangan Sebagai Dasar Dalam Penilaian Kinerja Keuangan PT. Budi Satria Wahana Motor. Jurnal Akuntansi \&Keuangan. Vol 5. No. 1, Maret 2014.

Sabihaini. 2006. Analisis Pemanfaatan Teknologi Informasi Dan Kinerja Individual (Studi Pada Rumah Sakit di Yogyakarta). Jurnal Widya Manajemen \&Akuntansi, Vol 6. No.1 April 2006. hal 1-16.

Salmiah, N. et al . 2015. Analisis Penerapan Akuntansi Pada UMKM Binaan Dinas Koperasi dan UMKM Kota Pekanbaru dan Kesesuaiannya dengan Standar Akuntansi Keuangan Entitas Tanpa Akuntabilitas Publik (SAK ETAP) (studi kasus pada UMKM Kecamatan Sukajadi di Kota Pekanbaru).

Salmiah,S. \& Nanda, S.T (2017). FaktorFaktor Yang Mempengaruhi Penggunaan Informasi Akuntansi Pada Umkm Di Kota Pekanbaru.

Sutton, Stave G. 2000. The Changing Face of Acoounting in an Information Technology Dominated World.
International journal of Accounting Information Systems.Vol 1, 2008 hal 1-8.

Theng, Lau, Geok, and Jasmine Wang Boon. 1996. An Explanatory Study of Factors Affecting The Failure of Local Small and Medium Entrprises. Asia Pasific Journal of Management. Singapore

Thompson,R,.L. Higgins,C.A. Howell, J.M. 1991. Personal Computing : Toward a Conceptual Model of Utilization. MIS Quarterly, Vol. 15, No. 1 (Mar., 1991), pp. 125-143.

Umar, Husein. 2003 . Metodologi Penelitian Aplikasi Dalam Pemasaran. Jakarta : Gramedia Pustaka Umum.

Xiao, Z.Z. Dyson,J.R. \& Powell, P.L. 1996. The Impact of Information Technology On Corporate Financial Reporting:A Contigency Prespective. The British Accounting Review, Vol 28. No 3, hal : 203-227

http://bisnis.tempo.co/read/news/2015/07/0 7/087681967/penyalurankurrangsang-pertumbuhan-usahamikro. 